\title{
Penggunaan Setrategi Murder dalam Pembelajaran Pendiidkan Agama Islam di Sekolah Dasar Negei 6 Penujak Lombok Tengah Tahun Pelajaran 2018
}

\author{
Bq. Hadia martanti \\ Dosen IAQH BAGU \\ e-mail hadia.martanti@gmail.com
}

\begin{abstract}
The purpose of this study was to determine the effect of the MURDER strategy on the learning outcomes of students' Islamic religious education. This research is an experimental research. The subject of the study were 52 grade $V$ students of SDN 6 penujak, 30 female students and 22 male students. This study is a quasi-experimental study that uses two samples, namely the experimental group and the control group. The data planning method used is an objective form test.

The results of the study showed that the experimental group learning outcomes were more increased than the control group learning outcomes. After analyzing the data about learning using MURDER strategy in the study program the average value of students was 75.4 with a completeness percentage of $85 \%$ while the average value of students who used the conventional method reached 66.8 with a completeness percentage of $68 \%$. Based on the results of the study, it can be concluded that the MURDER strategy has a positive effect on students' mathematics learning outcomes compared to learning using conventional methods.
\end{abstract}

Kata kunci : hasil belajar, strategi MURDER

\section{PEDAHULUAN}

Pendidikan adalah suatu system yang berakar atau bersumber pada filsapat hidup. Dalam filsapat hidup inilah tercermin nilai-nilai yang dianut dan gambaran manusia yang dicita-citakannya, yang kemudian akan menjadi dasar dan tujuan pendidikan.

Selain itu, pendidikan akan berarti dan dapat meningkatkan kualitas sumber daya manusia secara keseluruhan. Peningkatan kualitas pendidikan merupakan kebijaksanaan dan program yang harus dilaksanakan secara optimal. Sumber Daya Manusia (SDM) yang diharapkan sebagai penggerak dan motivator 
pembangunan tidak terlepas dari bagaimana pendidikan menghasilkan tenaga terampil yang bergerak dalam bidang masing-masing. Dengan kata lain, pendidikan perlu menghasilkan lulusan yang berkualitas. Pendidikan adalah suatu proses dalam rangka mempengaruhi peserta didik supaya mampu menyesuaikan diri sebaik mungkin dengan masyarakat.

Pembelajaran merupakan salah satu unsur penentu baik tidaknya lulusan yang dihasilkan oleh suatu system pendidikan. Pembelajaran yang baik cendrung menghasilkan lulusan yang baik pula, begitu juga sebaliknya. Di dalam UUD Sistem pendidikan nasional no 20 tahun 2003 tentang system pendidikan nasional menyatakan, "pendidikan diselenggarakan dengan memberikan keteladanan, membangun kemauan, dan mengembangkan kretivitas pserta didik dalam proses pembelajaran".

Pedidikan agama islam merupakan suatu mata pelajaran yang sangat pundamental di sekolah dasar, sebab dengan menanamkan agama pada peserta didik akan memberikan suatu sikap yang baik dan bisa menjadi perisai dalam bergaul. Selain itu pembelajran agama islam di sekolah dasar sangat besar pengaruhnya terhadap nilai spiritual siswa, sebab dengan menanamkan pmbelajaran agama islam pada siswa akan mengetahui bagaimana tata cara beribadah kepada tuhan, seperti sholat, puasa, zakat dan lain sebagainya.

\section{PENGERTIAN PAI}

Pendidikan Agama Islam adalah upaya sadar dan terencana dalam menyiapkan peserta didik untuk mengenal, memahami, menghayati hingga 
mengimani, bertaqwa, dan berakhlak mulia dalam mengamalkan ajaran agama Islam dari sumber utamanya kitab suci Al Qur an dan Hadits, melalui kegiatan bimbingan, pengajaran, latihan, serta penggunaan pengalaman. Dibarengi tuntunan untuk menghormati penganut agama lain dalam hubunganya dengan kerukunan antar ummat beragama dalam masyarakat hingga terwujud kesatuan dan persatuan bangsa. ${ }^{1}$

Mata pelajaran Pendidikan Agama Islam itu keseluruhannya terliput dalam lingkup: Al Qur an dan Hadits, Keimanan, Akhlak, dan Fiqh/Ibadah. Sekaligus menggambarkan bahwa ruang lingkup Pendidikan Agama Islam mencakup perwujudan keserasian, keselarasan dan keseimbangan hubungan manusia dengan Allah SWT, diri sendiri, sesama manusia, makhluk lainnya maupun lingkungannya (Hablun minallah wa hablun minannas). ${ }^{2}$

Fungsi

Pendidikan Agama Islam di SD berfungsi untuk : (a) Penanaman nilai ajaran Islam sebagai pedoman mencapai kebahagiaan hidup di dunia dan akhirat; (b) Pengembangan keimanan dan ketakwaan kepada Allah SWT serta akhlak mulia peserta didik seoptimal mungkin, yang telah ditanamkan lebih dahulu dalam lingkungan keluarga; (c) Penyesuaian mental peserta didik terhadap lingkungan fisik dan sosial melalui pendidikan agama Islam; (d) Perbaikan kesalahan-kesalahan, kelemahan-kelemahan peserta didik dalam keyakinan,

${ }^{1}$ http://zainuddin.lecturer.uin-malang.ac.id/2013/11/13/agama-islam-sd/ Di akses hari jum'at 22 september 2018. Puku 5:41 PM

${ }^{2}$ Ibid.. http://zainuddin.lecturer.uin-malang.ac.id/2013/11/13/agama-islam-sd/ Di akses hari jum'at 22 september 2018. Puku 5:41 PM 
pengamalan ajaran agama Islam dalam kehidupan sehari-hari; (e) Pencegahan peserta didik dari hal-hal negatif budaya asing yang akan di hadapinya sehari-hari; (f) Pengajaran tentang ilmu pengetahuan keagamaan secara umum ( alam nyata dan non nyata ), sistem dan fungsionalnya; (g) Penyaluran siswa untuk mendalami pendidikan agama ke lembaga pendidikan yang lebih tinggi. ${ }^{3}$

\section{Tujuan}

Pendidikan Agama Islam di SD bertujuan untuk menumbuhkan dan meningkatkan keimanan, melalui pemberian dan pemupukan pengetahuan, penghayatan, pengamalan serta pengalaman peserta didik tentang agama Islam sehingga menjadi manusia muslim yang terus berkembang dalam hal keimanan, ketaqwaannya kepada Allah SWT serta berakhlak mulia dalam kehidupan pribadi, bermasyarakat, berbangsa dan bernegara, serta untuk dapat melanjutkan pada jenjang pendidikan yang lebih tinggi. ${ }^{4}$

\section{Karekteristik Siswa Sekolah Dasar}

Anak SD usia 6 sampai12 tahun banyak mengalami perubahan fisik maupun mental, akibat dari faktor internal maupun eksternal yakni lingkungan keluarga, sekolah, masyarakat dan juga teman sebaya. Dalam Pembelajaran Pendidikan Agama Islam setiap materi yang baru dipahami siswa perlu segera

\footnotetext{
${ }^{3}$ Ibid.. http://zainuddin.lecturer.uin-malang.ac.id/2013/11/13/agama-islam-sd/ Di akses hari jum'at 22 september 2018. Puku 5:41 PM

${ }^{4}$ Ibid.. http://zainuddin.lecturer.uin-malang.ac.id/2013/11/13/agama-islam-sd/ Di akses hari jum'at 22 september 2018. Puku 5:41 PM
} 
diberi penguatan agar mengendap dan bertahan lama dalam ingatan siswa, sehingga siswa akan selalu mengingatnya.

\section{Strategi belajar}

Banyak pendapat para ahli yang mendefinisikan strateegi belajar mengajar dengan berbagai istilah dan pengertiannya yang berbeda, meski perbedaan tersebut sebenarnya hanya terletak pada aksentuasinnya saja. Menurut Sunhaji strategi belajar mengajar adalah usaha nyata guru dalam praktik mengajar yang dinilai lebih efektif dan efesien atau politik dan taktik Guru yang dilaksanakan dalam praktik mengajar di kelas. ${ }^{5}$

Dick and Cerey menjelaskan bahwa strategi belajar terdiri atas seluruh komponen materi pembelajaran dan prosedur atau tahapan kegiatan belajar yang akan digunakan oleh Guru dalam rangka membantu peserta didik mencapai tujuan pembelajaran tertentu. ${ }^{6}$ Gropper mendefinisikan Strategi pembelajaran merupakan pemilihan atas berbagai jenis latihan tertentu yang sesuai dengan tujuan pembelajaran yang ingin dicapai. ${ }^{7}$

Dari beberapa pendapat para ahli, dapat disimpulkan bahwa strategi pembelajaran merupakan cara-cara yang akan dipilih dan digunakan oleh seorang pengajar unntuk menyampaikan materi pembelajaran sehingga akan memudahkan peserta didik menerima dan memahami materi pembelajaran yang pada ahirnya tujuan pembelajaran dapat dikuasainya diahir kegiatan belajar.

\footnotetext{
${ }^{5}$ Sunhaji. Strategi Pembelajaran. (STAIN Purwokerto Press: Yogyakarta. 2009).hal.1

${ }^{6}$ Hamzah B. Uno .Model Pembelajaran. (PT Bumi Aksara: Jakarta. 2010). Hal.1

${ }^{7}$ Ibid..hamzah..hal...1
} 


\section{Pengertian MURDER}

Pembelajaran MURDER merupakan salah satu model kooperatif yang dihasilkan dari persepektif psikologi kognitif. Murder merupakan gabungan dari beberapa kata yang meliputi: Pertama. Mood (Suasana Hati) adalah istilah bahasa inggris yang artinya suasana hati. Dalam belajar suasana hati yang positif bisa menciptakan semangat belajar sehingga konsentrasi belajar dapat dicapai semaksimal mungkin dan dapat menyerap apa yang telah dipelajari. Oleh karena itu, jika suasana hati tidak mendukung, maka semua konsentrasi akan dibuyarkan dengan pikiran-pikiran yang tidak penting untuk difikirkan. Ciptakan suasana hati yang positif ketika kita belajar sebuah ilmu.

Kedua, Understand (Pemahaman) Menurut kamus besar Bahasa Indonesia yang diterbitkan Departemen Pendidikan dan Kebudayaan, pemahaman adalah mengerti benar atau mengetahui benar. Pemahaman dapat diartikan juga menguasai tertentu dengan pikiran, maka belajar berarti harus mengerti secara mental makna dan filosofisnya, maksud dan implikasi serta aplikasi-aplikasinya, sehingga menyebabkan siswa memahami suatu situasi. Hal ini sangat penting bagi siswa yang belajar. Memahami maksudnya, menangkap maknanya, adalah tujuan akhir dari setiap mengajar. Pemahaman memiliki arti mendasar yang meletakan bagian-bagian belajar pada proporsinya. Tanpa itu, maka skill pengetahuan dan sikap tidak akan bermakna.

Ketiga, Recall (Pengulangan) adalah usaha aktif untuk memasukkan informasi kedalam ingatan jangka panjang. Ini dapat dilakukan dengan "mengikat" fakta kedalam ingatan visual, auditorial, atau fisik. Otak banyak 
memiliki perangkat ingatan. Semakin banyak perangkat (indra) yang dilibatkan, semakin baik pula sebuah informasi baru tercatat. Me-recall tidak hanya terhadap pengetahuan tentang fakta, tetapi juga mengingat akan konsep yang luas, generalisasi yang telah didistribusikan, definisi, metode dalam mendekati masalah. Me-recall, bertujuan agar siswa memiliki kesempatan untuk membentuk atau menyusun kembali imformasi yang telah mereka terima. ${ }^{8}$

Langkah- langkah penerapan strategi pembelajaran MURDER adalah sebagai berikut: Langkah pertama berhubungan dengan suasana hati (mood) adalah ciptakan suasana hati yang positif untuk belajar. Hal ini bisa dilakukan dengan cara menentukan waktu, lingkungan dan sikap belajar yang sesuai dengan kepribadian siswa. Langkah kedua berhubungan dengan pemahaman adalah segera tandai bahan pelajaran yang tidak dimengerti. Pusatkan perhatian pada mata pelajaran tersebut atau ada baiknya melakukan bersama beberapa kelompok latihan.

Langkah ketiga berhubungan dengan pengulangan adalah setelah mempelajari satu bahan dalam suatu mata pelajaran, segeralah berhenti. Setelah itu, ulangi membahas bahan pelajaran itu dengan kata-kata siswa. Langkah keempat yang berhubungan dengan penelaahan adalah segera kembali pada bahan pelajaran yang tidak dimengerti. Carilah keterangan mengenai mata pelajaran itu dari artikel, buku teks atau sumber lainnya. Jika masih belum bisa, didiskusikan dengan Guru atau teman kelompok. Langkah kelima berhubungan dengan pengembangan adalah tanyakan pada siswa mengenai materi yang sudah

\footnotetext{
${ }^{8}$ Jamarah. Strategi Pembelajaran Berorientasi Standar Proses Pendidikan. Prenada medi group: Jakarta. 2005).hal.108
} 
dipelajari. Langkah keenam yang berhubungan dengan review adalah pelajari kembali materi pelajaran yang sudah dipelajari.

\section{Hasil Belajar}

Hasil belajar dapat dijelaskan dengan memahami dua kata yang membentuknya, yaitu "hasil" dan "belajar". Pengertian hasil (product) mnunjukkan pada suatu prolehan akibat dilakukannya suatu aktifitas atau proses yang mengakibatkan berubahnya input secara fungsional. Belajar dilakukan untuk mengusahakan adanya perubahan prilaku pada individu yang belajar. Perubahan prilaku itu merupakan prolehan yang menjadi hasil belajar. ${ }^{9}$ Menurut Winkel hasil belajar adalah perubahan yang mengakibatkan manusia berubah dalam sikap dan tingkah lakunya. ${ }^{10}$ Pengertian hasil belajar juga dikemukakan oleh Risda hasil belajar merupakan hasil yang diperoleh atau dicapai oleh siswa pada bidang studi tertentu dengan menggunakan tes atau evaluasi sebagai alat pengukur keterampilan. $^{11}$

Pendapat lain tentang hasil belajar dikemukan oleh Sudjana, Hasil belajar adalah kemampuan-kemampuan yang dimiliki siswa setelah menerima pengalaman belajarnya. ${ }^{12}$ Hasil belajar dapat pula berupa kemampuan ranah kognitif. Kemampuan kognitif merupakan salah satu bagian dari hasil belajar. Menurut Sulaeman bahwa"hasil belajar siswa adalah hasil-hasil yang dicapai

\footnotetext{
${ }^{9}$ Purwanto. Evaluasi Hasil Belajar. (Pustaka Pelajar : Yogjakarta. 2011).hal.44-45

${ }^{10}$ Ibid..purwanto..hal..45

${ }^{11}$ Sunarto. Pengantar Evaluasi Pendidikan. (Pustaka Pelajar: Yogyakrta. 2006).hal.6

(http://www.sarjanaku.com/2011/03/pengertian-definisi-hasil-belajar.html diakses tanggal 03 september , 2018)
} 
ssiwa dalam suatu periode tertentu setelah dinilai oleh Guru yang ditunjukan dalam bentuk angka-angka (nilai-nilai). ${ }^{13}$

\section{Hasil Penelitian}

Berdasarkan hipotesis yang diajukan maka hasil penelitian dideskripsikan dalam bentuk deskripsi data. Deskripsi data berasal dari data yang dikumpulkan dalam penelitian. Data penelitian yang dimaksud berupa data hasil belajar dengan menggunakan strategi MURDER dan pembelajaran konvensional.

Penelitian dengan dua metode ini dilakukan terhadap dua sampel yaitu pada kelompok eksperimen dan kelompok control. Untuk kelas eksperimen dengan jumlah siswa sebanyak 27 orang dan kelompok control sebanyak 25 orang. Sehingga secara keseluruhan ada 52 orang yang digunakan sebagai sampel pada siswa kelas V SDN 6 penujak Lombok tengah 2018.

Deskripsi data tes hasil belajar PAI siswa dapat dilihat pada tabel 1 dibawah ini.

Tabel 1

Deskripsi Data Hasil Belajar PAI Siswa

\begin{tabular}{|l|l|l|l|l|c|}
\hline Kelompok & $\begin{array}{c}\text { Jumlah } \\
\text { Siswa }\end{array}$ & $\begin{array}{c}\text { Nilai } \\
\text { Tertinggi }\end{array}$ & $\begin{array}{c}\text { Nilai } \\
\text { Terendah }\end{array}$ & Rata-rata & SD \\
\hline Eksperimen & 27 & 95 & 35 & 75,4 & 17,5 \\
\hline Control & 25 & 100 & 35 & 66,8 & 17,7 \\
\hline
\end{tabular}

13 (http://www.sarjanaku.com/2011/03/pengertian-definisi-hasil-belajar.html diakses tanggal 03 september ,2018) 
Berdasarkan tabel 1 terlihat bahwa hasil belajar siswa pada kelompok eksperimen dan kelompok control berbeda. Pada kelas eksperimen nilai tertinggi adalah 95 dan nilai terndah adalah 35 dengan nilai rata-rata 75,4 dan standar deviasi 17,5 . Sedangkan pada kelompok control nilai tertinggi adalah 100 dan nilai terndah adalah 35 dengan nilai rata-rata 66,8 dan standar deviasi 17,7.

Adapun untuk persentasi ketuntasan individu maupun ketuntasan klasikal kelompok eksperimen dan kelompok control dapat dilihat pada tabel 2.

Tabel 2

Tabel persentase ketuntasan kelompok eksperimen dan kelompok kontrol

\begin{tabular}{|c|c|c|c|}
\hline Kelompok & Jumlah siswa & $\begin{array}{c}\text { Ketuntasan } \\
\text { individu }\end{array}$ & $\begin{array}{c}\text { Ketuntasan } \\
\text { klasikal }\end{array}$ \\
\hline Eksperimen & 27 & 23 & $85 \%$ \\
\hline Control & 25 & 17 & $68 \%$ \\
\hline
\end{tabular}

\section{Pengujian Persyaratan Analisis}

Pengujian persyaratan analisis dilakukan untuk memberikan gambaran sejauh mana asumsi-asumsi persyaratan analisis dapat dipenuhi sesuai dengan teknik analisis data yang telah direncanakan. Uji persyaratan analisis yan dilakukan dalam penelitian ini adalah uji normalitas dan uji homogenitas

\section{Uji Normalitas Data}

Pembuktian normalitas data dilakukan untuk menguji apakah skor yang telah diteliti menghampiri distribusi normal atau tidak. Pembuktian normalitas data tersebut dapat dilakukan dengan menggunakan rumus chi-kuadrat $\left(x^{2}\right)$. 
Tabel 3

Hasil Uji Normlitas Data

\begin{tabular}{|c|c|c|c|}
\hline Data & $x^{2}$ hitung & $x^{2}$ tabel & Keterangan \\
\hline Eksperimen & 9,533 & 12,592 & Normal \\
\hline kontrol & 2,966 & 11,070 & Normal \\
\hline
\end{tabular}

Dari tabel diatas, dapat disimpulkan bahwa tes kemampuan ahir tersebut berdistribusi normal karna $x^{2}$ hitung pada kedua data tersebut lebih kecil dari $x^{2}$ tabel untuk $\mathrm{dk}=(\mathrm{k}-1)$ pada tarap signifikan $5 \%$.

\section{Uji Homogenits}

Pengujian homogenitas data dimaksudkan untuk menguji apakah data yang dikumpulkan homogeny atau tidak. Pembuktian homogenitas data tersebut dapat dilakukan dengan tehnik uji bartllet

Tabel 4

Persiapan untuk uji homogenits data

\begin{tabular}{|c|c|c|c|c|}
\hline Data & Dk (n-1) & $s i^{2}$ & Log $s i^{2}$ & Dk.log $s i^{2}$ \\
\hline Eksperimen & 26 & 307 & 2,487 & 64,662 \\
\hline Control & 24 & 313 & 2,496 & 59,904 \\
\hline Jumlah & 50 & & & 124,556 \\
\hline
\end{tabular}

Dari hasil pengujian homogenitas data diperoleh $x^{2}$ hitung $=-0,025$ dan $x^{2}$ tabel $=0,95$ dimana $x^{2}$ hitung $<x^{2}$ tabel untuk $\mathrm{dk}=(\mathrm{k}-1)$ pada tarap signifikan 5\% sehingga data yang diproleh homogeny. Dengan adanya pengujian terhadap homogenitas data maka dapat dilanjutkan pengujian hipotesis. 


\section{Pengujian Hipotesis}

Untuk pengujian hipotesis, teknik uji hipotesis yang digunakan adalah analisis statistic uji-t untuk mengetahui pengaruh strategi MURDER terhadap hasil belajar matematika siswa SDN 6 penujak tahun pelajaran 2018.

Dengan kriteria sebagai berikut :

a. Ho ditolak jika $t_{\text {hit }}>t_{\text {tabel }}$

b. Ho tidak ditolak jika $t_{\text {hit }}<t_{\text {tabel }}$

Berdasarkan perhitungan hipotesis pada lampiran 17. Didapatkan hasil

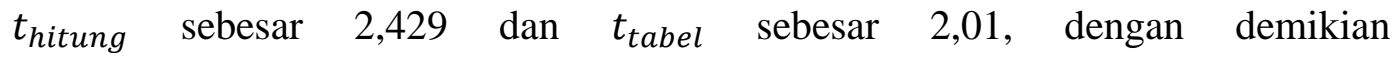
$t_{\text {hitung lebih besar dari }} t_{\text {tabel }}$. Itu artinya $H_{o}$ ditolak dan $H_{a}$ diterima. Berarti strategi MURDER berpengaruh dalam meningkatkan hasil belajar matematika siswa jika dibandingkan dengan metode konvensional.

\section{Pembahasan Hasil Penelitian}

Berdasarkan analisis data menunjukkan bahwa $H_{o}$ ditolak . Ini berarti bahwa siswa yang diajarkan menggunakan strategi MURDER dan konvensional memiliki perbedaan. Kedua pembelajaran ini memberikan kontribusi berbeda terhadap hasil belajar siswa sesuai dengan hasil tes yang dilakukan pada ranah kognitif.

Hasil penelitian menunjukkan nilai rata-rata pada kelompok eksperimen 75,4 dengan standar deviasi 17,5 dan nilai rata-rata pada kelompok control 66,8 dengan standar deviasi 17,7. Sedangkan persentase ketuntasan individu untuk 
kelompok eksperimen adalah 23 orang dengan persentase klasikal sebesar $85 \%$. adapun untuk kelompok control persentase ketuntasan indvidu sebanyak 16 orang dengan persentase klasikal sebesar $62 \%$.

Berdasarkan hasil pengujian hipoteis dalam penelitian dengan menggunakan uji t-tes dan dari dari perhitungan statistiknya diproleh $t_{\text {hitung }}$ 2,429 dan $t_{\text {tabel }}$ dengan tarap kepercayaan 5\% diprolh $t_{\text {tabel }}$ 2,01 sehingga $t_{\text {hitung }}$ lebih besar dari $t_{\text {tabel. }}$ Hasil pengujian hipotesis disini adalah $H_{o}$ ditolak dan $H_{a}$ diterima.

\section{Kesimpulan}

Berdasarkan hasil pengujian data dan hipotesis, hasil belajar antara kelompok eksperimen dengan kelompok control sangatlah berbeda, baik dilihat dari hasil ketuntasan belajar secara individual , ketuntasan klasikal maupun nilai rata-ratanya. Siswa yang tuntas pada kelompok eksperimen sebanyak 23 orang dengan ketuntasan klasikal sebesar $85 \%$ serta nilai rat-rat mencapai 75,4 . Adapun untuk kelompok control, siswa yang tuntas sebanyak 16 orang dengan persentase ketuntasan klasikal sebesar $68 \%$ dan nilai rata-rata mencapai 66,8. Maka dapat ditarik kesimpulan yaitu strategi MURDER berpengaruh positif dalam meningkatkan hasil belajar matematika siswa pada mata pelajaran pendidikan agama islam 


\section{DAFTAR PUSTAKA}

Anas Sudijono (2010) Pengantar Statistik Pendidikan. PT Rajagrapinda Persada : Jakarta.

Eri Murnia Ningsih. 101 Tips Belajar Efektif dan Menyenangkan. Semarang: PT sindo press

Furqon (2009) Statistik Terapan Untuk Penelitian.Alfabeta: Bandung

Hamzah B. Uno (2010). Model Pembelajaran. PT Bumi Aksara: Jakarta.

Heruman (2008) Model Pembelajaran Matematika SD, PT Remaja Rosda Karya : Bandung.

jamarah (2005). Strategi Pembelajaran Berorientasi Standar Proses Pendidikan. Prenada medi group: Jakarta

Nana Syaodih Sukmadinata. (2011). Metode Penelitian Pendidikan. PT remaja Rosda Karya: Bandung.

Mardalis (2009). Metode Penelitian Suatu Pendekatan Proposal. PT Bumi Akasara: Jakarta.

Nyimas aisyah (2007). Pengembangan pembelajaran matematika SD : Direktorat jendral pendidikan tinggi Departemen pendidikan nasional.

Purwanto (2011) Evaluasi Hasil Belajar. Pustaka Pelajar : Yogjakarta. 
Syaifudin Azhar. (2007). Tes Prestasi Fungsi Pengembangan Pengukuran Prestasi Belajar. Yogyakarta: Pustaka Belajar.

Sugiyono (2010). Metode penelitian kuantitatif kualitatif dan R\&D. Alfabeta: Bandung.

Sunhaji (2009). Strategi Pembelajaran. STAIN Purwokerto Press: Yogyakarta.

Sunarto (2006). Pengantar Evaluasi Pendidikan. Pustaka Pelajar: Yogyakrta.

Zainal Arifin (2011). Evaluasi Pembelajaran : PT Remaja Rosda Karya. Bandung.

http://zainuddin.lecturer.uin-malang.ac.id/2013/11/13/agama-islam-sd/ Di akses hari jum'at 22 september 2018. Puku 5:41 PM

http;// en.wikipedia.org.wiki/Definitions of_mathematics,2009

http://www.sarjanaku.com/2011/03/pengertian-definisi-hasil-belajar.html

http://biologi.fkip.uns.ac.id/wp-content/uploads/2012/02/SKRIPSI-DISKA.pdf 